\title{
Trophic ecology of the gopher rockfish Sebastes carnatus inside and outside of central California marine protected areas
}

\author{
Erin K. Loury ${ }^{1,3, *}$, Shannon M. Bros ${ }^{2}$, Richard M. Starr ${ }^{1}$, David A. Ebert ${ }^{1}$, \\ Gregor M. Cailliet ${ }^{1}$
}

\author{
${ }^{1}$ Moss Landing Marine Laboratories, 8272 Moss Landing Road, Moss Landing, California 95060, USA \\ ${ }^{2}$ San José State University, 1 Washington Square, San Jose, California 95192, USA \\ ${ }^{3}$ Present address: FISHBIO, 1617 South Yosemite Avenue, Oakdale, California 95361, USA
}

\begin{abstract}
Marine protected areas (MPAs) can potentially alter food web dynamics by increasing the density of fishes within their borders. Such increases in the density of potential competitors can cause generalist predators to contract the scope of their diets. This study investigated the effects of increased conspecific fish density on the diets of gopher rockfish Sebastes carnatus at a 35 yr old MPA in Point Lobos, California, and at 4 newly established MPAs in Año Nuevo, Point Lobos, Piedras Blancas, and Point Buchon in central California. Analyses were conducted for 707 stomachs collected from 2007 to 2009. Diets did not differ inside versus outside the old Point Lobos MPA in terms of prey richness, evenness, composition, or gopher rockfish trophic level. However, fish outside the MPA had greater levels of individual specialization. No consistent differences in these metrics were observed inside versus outside the 4 new MPAs, although prey composition and evenness did differ significantly among geographic locations. Diets at Año Nuevo, the most northern and shallow location, consisted predominantly of Cancer spp. and porcelain crabs (Porcellanidae), while diets from southern, deeper locations were dominated by brittle stars (Ophiuroidea). The case study of the old Point Lobos MPA indicates that fish feeding ecology may not change in an MPA after several decades. Differences in prey observed among geographic locations suggest variation in the community composition among central California's new MPAs, which may influence the effect of each MPA on food web dynamics over time.
\end{abstract}

KEY WORDS: Diet $\cdot$ Marine reserves $\cdot$ Feeding ecology $\cdot$ Sebastidae $\cdot$ Kelp forests

\section{INTRODUCTION}

The decline of many fisheries and coastal marine ecosystems around the world has prompted the increasing adoption of marine protected areas (MPAs) as ecosystem-based management practices that can protect both marine species and ecosystem services (Allison et al. 1998, Crowder et al. 2008). Fishing directly alters marine ecosystems through the removal of fishes and indirectly alters them through changes in marine food webs resulting from the loss

\footnotetext{
*Corresponding author: erin.loury@gmail.com
}

of predators and prey (Botsford et al. 1997, Pinnegar et al. 2000). In turn, MPAs that exclude fishing pressure within their borders can directly affect marine communities by increasing the density and size of fishes (McClanahan \& Arthur 2001, Halpern \& Warner 2002, Micheli et al. 2004, Guidetti \& Sala 2007, Tetreault \& Ambrose 2007, Lester et al. 2009). A greater abundance of predators inside MPAs can subsequently trigger indirect effects that cascade down multiple trophic levels via predator-prey interactions, sometimes altering community structure by

() The authors 2015. Open Access under Creative Commons by Attribution Licence. Use, distribution and reproduction are unrestricted. Authors and original publication must be credited. 
changing the abundance and distribution of prey species and primary producers (Babcock et al. 1999, Guidetti 2006, Mumby et al. 2007).

Recognizing the need to protect California's marine species and habitats from human impacts, the California Department of Fish and Game passed the Marine Life Protection Act in 1999, which called for a network of MPAs to span the California coast. The first section of this statewide network was established in central California in April 2007, when the California Fish and Game Commission adopted 29 MPAs between Pigeon Point and Point Conception. These MPAs, effective as of September 2007, include 13 no-take state marine reserves that prohibit all commercial and recreational fishing within their borders and 15 state marine conservation areas, which permit limited fishing. In addition to creating new MPAs, the act expanded the pre-existing Point Lobos State Marine Reserve, which has been closed to fishing since 1973. As one of the oldest no-take marine reserves in the USA, Point Lobos offers a unique opportunity to examine the long-term effects of fishing exclusion inside an MPA, including potential effects on marine food webs.

Studying fish feeding habits inside and outside of MPAs provides a means to investigate potential indirect effects of increased fish density on marine food webs. While previous studies have looked for the effects of MPAs across trophic levels, such as the effects of specialist predators on the distribution of their prey and organisms at lower trophic levels (Babcock et al. 1999, McClanahan 2000, Fanshawe et al. 2003, Guidetti 2006, Clemente et al. 2009), few studies have focused within a trophic level to investigate the indirect effects of fishing exclusion on a single predator's feeding habits (Badalamenti et al. 2008, Fanelli et al. 2009, 2010, Sinopoli et al. 2012). The increased density of competitors inside MPAs is one potential factor that could cause within-trophiclevel diet changes. Manipulative experiments using three-spined sticklebacks Gasterosteus aculeatus have demonstrated that increased densities of conspecifics can lead to increased diet specialization (Svanbäck \& Bolnick 2007), supporting the theory that competing populations will diverge from each other in resource use (Brown \& Wilson 1956). Changes in a single species' diet can therefore be used to infer changes in ecological relationships between a predator and its prey as well as the indirect effects of increased competitor densities in MPAs.

The gopher rockfish Sebastes carnatus was chosen to investigate potential changes in feeding ecology at 4 MPAs located in central California: Año Nuevo,

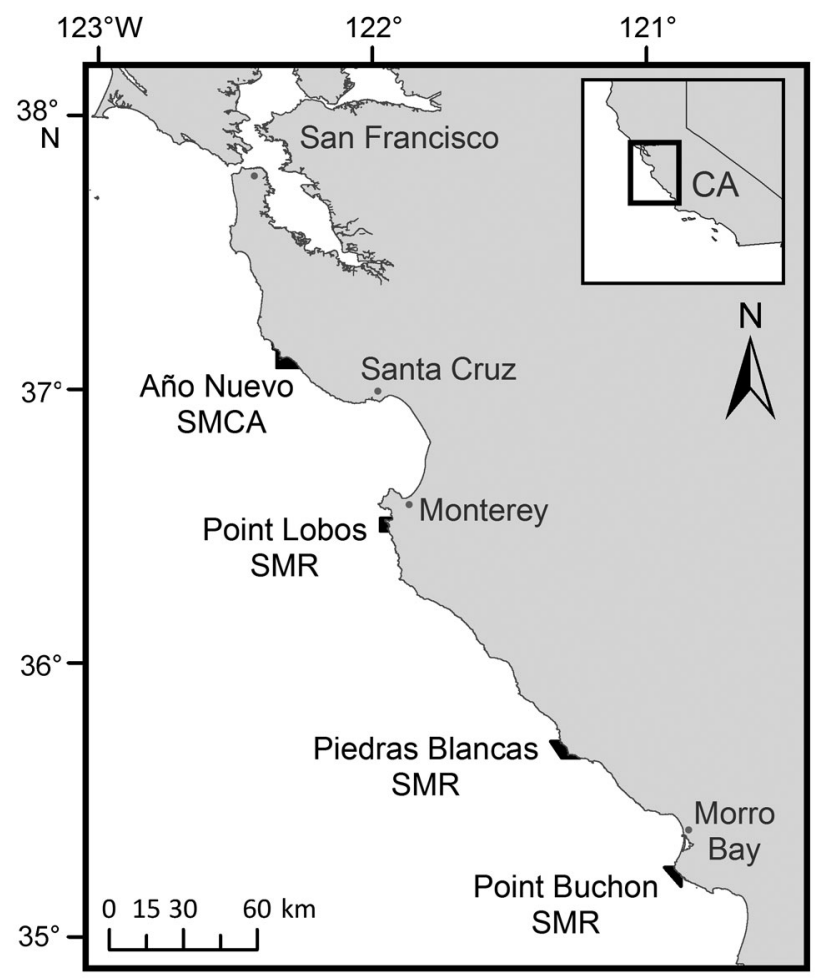

Fig. 1. Marine protected areas (MPAs) in 4 geographic locations within the central California study area (shown in inset). MPAs include the Año Nuevo State Marine Conservation Area (SMCA) and the Point Lobos, Piedras Blancas, and Point Buchon state marine reserves (SMRs)

Point Lobos, Piedras Blancas, and Point Buchon (Fig. 1). The gopher rockfish is one of the most commonly occurring nearshore fishes in central California (Yochum et al. 2011) and is frequently caught in recreational and commercial live-fish fisheries (Key et al. 2005). Its abundance, territorial behavior, restricted movements, and generalist feeding habits (Larson 1980) make it a good candidate to investigate localized changes in food web structure that may occur in protected areas.

Differences in gopher rockfish density at the study locations enable an investigation of potential MPA effects. Baseline monitoring surveys from 2007 to 2009 in the MPAs chosen for this study documented significantly greater gopher rockfish densities inside MPAs compared to nearby fished areas at 3 of the 4 study locations (Starr et al. 2010, 2015). At the Point Lobos MPA, established in 1973, these differences in gopher rockfish density inside versus outside the MPA could possibly be a result of more than $30 \mathrm{yr}$ of MPA protection; however, at the new MPAs, these differences represent a pre-existing baseline rather than a direct result of the new MPAs themselves. 
Nevertheless, pre-existing differences in fish density inside and outside of MPAs still provide an opportunity to examine the effects of differing fish densities on feeding ecology. Such effects could be amplified if fish densities increase in the MPAs over time.

The goal of this study was to investigate the effects of fishing exclusion and increased conspecific densities on the feeding ecology of the gopher rockfish in central California MPAs. Specific objectives were to (1) assess the long-term effects of fishing exclusion by comparing gopher rockfish diets inside and outside of an MPA that has been established for more than $30 \mathrm{yr}_{\text {, }}(2)$ assess the short-term effects of fishing exclusion across the central California region by comparing gopher rockfish diets inside and outside of 4 newly established MPAs, and (3) explore environmental factors that could potentially contribute to variation in gopher rockfish diet.

\section{MATERIALS AND METHODS}

\section{Study areas and sample collection}

This study investigated 4 MPAs and 4 corresponding reference areas surveyed by the California Collaborative Fisheries Research Program (CCFRP, Starr et al. 2015). Each MPA and reference area pair was located in a different geographic location (Fig. 1): Año Nuevo, Point Lobos, Piedras Blancas, and Point Buchon. These locations contain extensive nearshore rocky habitats representative of the central California coastal region. The 3 southernmost MPAs are state marine reserves that prohibit all fishing. The Año Nuevo MPA is a state marine conservation area that prohibits all fishing but permits the hand harvest of giant kelp; however, kelp harvesting in this area has never occurred. To assess the impacts of excluding fishing pressure inside the MPAs, a reference area that had no restrictions on fishing was sampled near each MPA for comparison. Each reference area shared similar size, depth, habitat, and oceanographic conditions with the nearby MPA (Yochum et al. 2011). The Point Lobos MPA, established in 2007, encompasses the pre-existing Point Lobos Ecological Reserve (Fig. 2), which was closed to fishing in 1973. The area encompassed by the 1973 boundary will hereafter be referred to as the old Point Lobos MPA, and the area inside the extended 2007 boundary will be referred to as the new Point Lobos MPA.

Within each MPA and reference area, grid cells measuring $500 \times 500 \mathrm{~m}$ were delineated as part of the

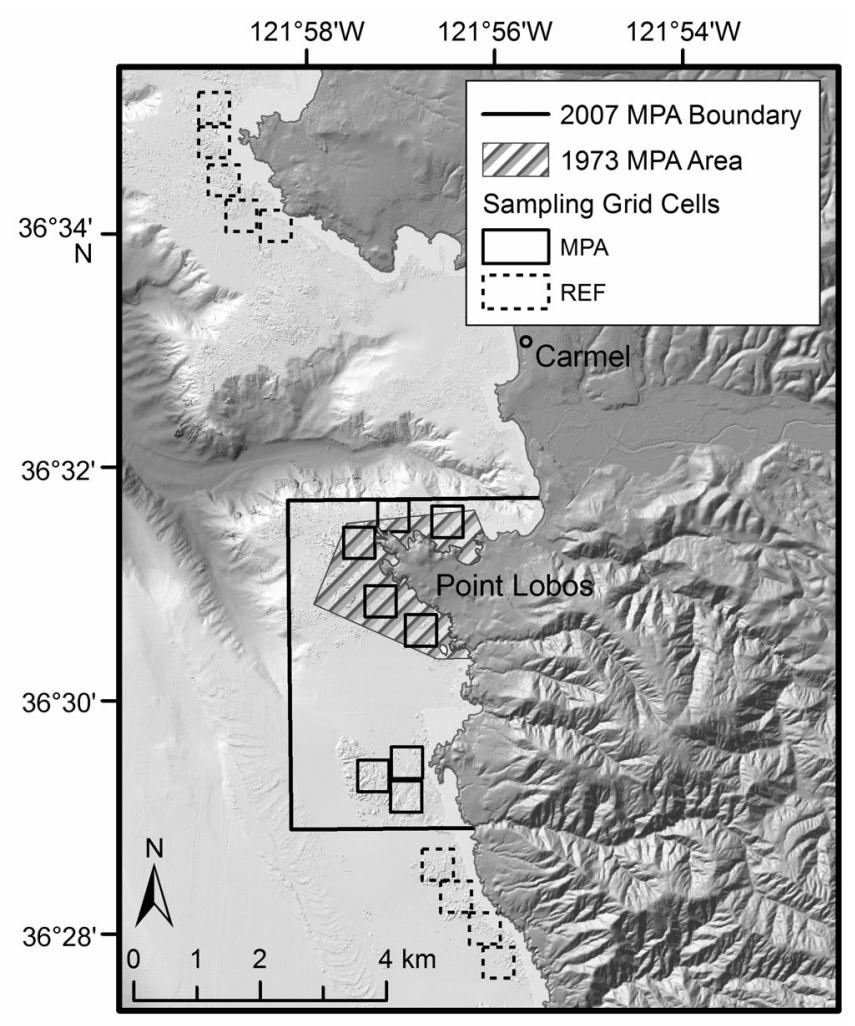

Fig. 2. Marine protected area (MPA) and reference (REF) area sampling sites at Point Lobos. Grid cells measuring 500 $\times 500 \mathrm{~m}$ were established in both the MPAs and REF areas. The shaded area denotes the boundary of the old Point Lobos MPA, closed to fishing in 1973. The solid line denotes the expanded boundary of the new Point Lobos MPA, established in 2007. Dotted lines represent grid cells in the unprotected REF areas

CCFRP sampling protocol, with similar numbers of grid cells located in the MPA and reference areas at each geographic location (Wendt \& Starr 2009, Starr et al. 2010). At Point Lobos, grid cells were delineated in both the old and new sections of the MPA. Gopher rockfish were collected with hook-and-line and trapping gear in the summer and fall of 2007 to 2009 as part of monitoring surveys conducted by the CCFRP (Wendt \& Starr 2009, Yochum et al. 2011). The great majority of samples were collected during hook-and-line surveys. Each location was sampled for $4 \mathrm{~d}$ each month from August to October 2007, from July to September 2008, and in July and August 2009. The Piedras Blancas MPA and corresponding reference area were added to the survey in 2008 ; thus, no fish were collected at Piedras Blancas in 2007. Four of the grid cells in a given MPA or reference area were randomly chosen and sampled each day, and a portion of the gopher rockfish catch was retained haphazardly. 
Care was taken to retain fish, whenever possible, that did not show extruded stomachs or regurgitated stomach contents. Any prey items found in the oral cavity were saved with the fish to be included in later dietary analysis. The retained fish were euthanized and placed on ice until the boat returned to shore, at which point they were frozen. Fish lengths and weights were measured to account for potential biases in feeding related to fish size. The total and standard lengths of each fish were measured to the nearest $1.0 \mathrm{~cm}$, and total fish weight was measured to the nearest $1.0 \mathrm{~g}$. Total lengths were compared inside and outside of MPAs using a randomized block design. The independent variable was whether an area was designated as an MPA or as a reference area. The dependent variable was total fish length for 31 fish randomly selected from each area to account for differences in sample size. A reference area was paired geographically with each of the 4 MPAs, allowing geographic location to be used as a blocking factor in a randomized complete block (RCB) ANOVA.

Fish were later partially thawed, and stomachs were removed and refrozen for later analysis. Fish with empty stomachs were excluded from analysis. Stomachs were thawed individually at room temperature, and the contents were examined with a dissecting microscope. The prey items of each stomach were identified to the lowest possible taxonomic level following Carlton (2007), enumerated, and weighed wet to the nearest $0.001 \mathrm{~g}$ after blotting away excess moisture. Bait used to catch fish was easily identified and thus excluded from dietary analysis. To minimize the effect of potential partial regurgitation, stomachs that contained less than $0.1 \mathrm{~g}$ of prey were considered empty and excluded from further dietary analysis. Prey were counted using the minimum number of individual prey items represented by the body parts present (Lance et al. 2001).

\section{Determining long-term effects of fishing exclusion at Point Lobos}

A difference in gopher rockfish density inside and outside of the old Point Lobos MPA provided the basis for investigating potential MPA effects on diet (Fig. 3, Starr et al. 2010, 2015). Diets were compared between fish collected at the old Point Lobos MPA and corresponding reference areas to assess the effects of increased conspecific densities after more than $30 \mathrm{yr}$ of fishing closure. Diets were compared using the following metrics: (1) richness, (2) even-

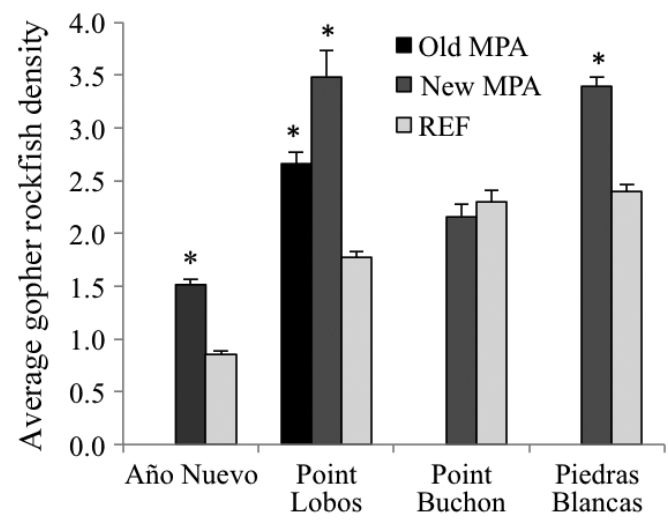

Fig. 3. Average gopher rockfish density at all study areas from 2007 to 2009 measured in catch per angler hour with hook and line. Vertical bars represent standard error. Asterisks indicate significant difference between marine protected areas (MPAs) and reference (REF) areas. Data from Starr et al. (2015)

ness, (3) composition, (4) trophic level, and (5) individual specialization (IS). The Point Lobos reference area consisted of 2 locations situated north and south of the MPA (Fig. 2). The results of a preliminary analysis, using the methods described in the subsequent paragraphs, indicated that diets in the north and south reference areas did not differ significantly from each other in terms of the 5 metrics listed above $(\mathrm{p}>0.05)$, except for prey taxon composition $(\mathrm{p}<$ $0.05)$. Therefore, these reference areas were pooled for subsequent comparison to the old MPA in all analyses except for prey taxon composition.

Diet richness, evenness, and composition were characterized by organizing prey into 18 taxonomic groups (Table 1). This classification strikes a balance between richness and ecological similarity by incorporating the lowest taxonomic groups to which prey were consistently identified and grouping taxa with highly similar morphologies and ecologies. These taxa exclude crabs and shrimp that could not be identified to the family level; sipunculans, urchins, and anemones, which were only encountered in 1 or 2 fish stomachs; and parasites or unidentified digested matter.

Richness and evenness. Prey accumulation as a function of number of samples was plotted to determine if sufficient samples were collected to characterize the diets of the MPA and reference areas (Ferry \& Cailliet 1996, Bizzarro et al. 2007). The relationship between number of samples and number of prey taxa observed was plotted using the specaccum function in the vegan community ecology package of the software program R 2.10.1 (Bizzarro et al. 2007, Oksanen et al. 2010). 
Table 1. Prey taxonomic groups used in dietary analysis

\begin{tabular}{|ll|}
\hline Prey taxon & Group(s) included \\
\hline Amphipod & Amphipoda \\
Brittle star & Ophiuroidea \\
Cancer crab & Cancer spp. \\
Cephalopod & Cephalopoda \\
Crangonid shrimp & Crangonidae \\
Fish & Actinopterygii \\
Hermit crab & Paguridae \\
Hippolytid shrimp & Hippolytidae \\
Isopod & Isopoda \\
Kelp crab & Epialtidae \\
Mollusc & Mollusca (excluding Cephalopoda) \\
Mysids & Mysidacea \\
Other crab & Grapsidae, Lithodidae, Panopeidae, \\
& Parthenopidae, Xanthidae \\
Pandalid shrimp & Pandalidae \\
Pistol shrimp & Alpheidae \\
Polychaete & Polychaeta \\
Porcelain crab & Porcellanidae \\
Spider crab & Pisidae \\
\hline
\end{tabular}

Diet evenness was calculated using Pielou's evenness measure $\left(J^{\prime}\right)$ :

$$
J^{\prime}=\frac{\sum p_{j} \log p_{j}}{\log n}
$$

where $p_{j}$ is the proportion of individuals that ate prey type $j$, and $n$ is the total number of prey types, or richness (Krebs 1999).

Prey composition. The contribution of each prey type to the diet was determined using prey-specific abundance (Amundsen et al. 1996, Brown et al. 2012) and percent occurrence (Cortés 1997). Prey-specific abundances by number and weight $\left(\% \mathrm{PN}_{i}, \% \mathrm{PW}_{i}\right)$ were calculated as:

$$
\% \mathrm{PA}_{i}=\frac{\sum_{j=1}^{n} \% \mathrm{~A}_{i j}}{n_{i}}
$$

where $\mathrm{A}_{i j}$ is the abundance by number or weight for prey $i$ in an individual stomach sample $j$, and $n_{i}$ is the number of stomachs containing prey $i$. Percent occurrence $\left(\% \mathrm{O}_{i}\right)$ was calculated as:

$$
\% \mathrm{O}_{i}=\frac{n_{i}}{n} \times 100
$$

The index of relative importance (IRI) is a compound index used to determine the importance of each prey type to the diet (Pinkas et al. 1971, Cortés 1997). A modified prey-specific version of the IRI (PSIRI) was calculated following Brown et al. (2012):

$$
\mathrm{PSIRI}_{i}=\left(\% \mathrm{PN}_{i}+\mathrm{PW}_{i}\right) \times \% \mathrm{O}_{i}
$$

The prey-specific calculation corrects for an inherent bias in the traditional calculation of IRI that overemphasizes the contribution of \%O (Brown et al. 2012). These PSIRI values were standardized as a percentage following Cortés (1997).

To reduce the effects of variation in diet biomass among fish of different sizes, differences in prey composition were investigated using standardized prey weights. These standardized weights were calculated for each stomach by dividing the raw weight of the prey taxon of interest by the weight of the fish to reduce the potential influence of fish size on prey quantity. Prey weight was used because it is an approximation of the energetic contribution of a prey type in an animal's diet, and it does not overemphasize the contribution of highly numerous prey items (Hyslop 1980). Prey composition was then determined at a population level by summing the standardized prey weights for an equal number of fish randomly drawn from the areas being compared.

To reduce the bias from unequal numbers of fish collected at each area, population totals for the old Point Lobos MPA and reference areas were calculated by randomly drawing 4 fish from each of 6 sampling grid cells in each area and summing the standardized prey weights of the 4 fish in each grid cell. These sample sizes included grid cells from both hook-and-line and trapping surveys and maximized the number of grid cells and number of fish per grid cell in each area.

A MANOVA (Quinn \& Keough 2002) was used to determine if prey composition differed between the MPA and 2 reference areas. Because the number of prey categories was large relative to the number of samples and could introduce type I error, a principal components analysis (PCA, Quinn \& Keough 2002) was first performed on total prey weights to reduce prey composition into 2 factors, which served as the dependent variables in the MANOVA. PCA and MANOVA were performed using the software package PASW Statistics 18.0.

Trophic level. The trophic level of each fish was calculated from stomach contents following Cortés (1999) and Ebert \& Bizzarro (2007):

$$
\mathrm{TL}_{k}=1+\left(\sum_{j=1}^{n} P_{j} \times \mathrm{TL}_{j}\right)
$$

where $\mathrm{TL}_{k}$ is the trophic level of species $k_{r} P_{j}$ is the proportion of prey category $j$ in the diet of species $k_{\text {, }}$ $n$ is total number of prey categories, and $\mathrm{TL}_{j}$ is the trophic level of prey category $j$. Percent weight values were used for $P_{j}$, and prey groups were assigned trophic levels following the characterization of Ebert \& Bizzarro (2007). An independent 2-sample $t$-test was used to detect differences in mean trophic level 
between the MPA and pooled reference areas. A linear regression was used to test for a relationship between trophic level and fish total length.

Individual specialization. IS was calculated following Bolnick et al. (2002). This index incorporates Czekanowski's proportional similarity index (PS), calculated as the overlap between an individual and the population:

$$
\mathrm{PS}_{i}=\sum_{j} \min \left(p_{i j}, q_{j}\right)
$$

where $\mathrm{PS}_{i}$ is the proportional overlap between individual $i$ and its population, $p_{i j}$ is the proportion of prey group $j$ by number in the individual $i$ 's diet, and $q_{j}$ is the proportion of prey group $j$ by number in the population as a whole.

The index of IS is then calculated as:

$$
\mathrm{IS}=\frac{1}{N} \sum_{i} \mathrm{PS}_{i}
$$

where $N$ is the total number of individuals in the population. Resulting values range from 0 to 1 , with 1 indicating complete overlap between individual diets and the population as a whole and lower values indicating greater specialization among individuals compared to the total population. An independent 2sample $t$-test was used to detect differences in IS values between the MPA and the reference area.

\section{Determining short-term effects of fishing exclusion at newly established MPAs}

Baseline differences in gopher rockfish densities inside and outside new MPAs provided the basis for an analysis of the effects of conspecific density on gopher rockfish diets across the central California region (Fig. 3, Starr et al. 2010, 2015). Diets were compared inside and outside of 4 MPAs established in 2007 at Año Nuevo, Point Lobos, Piedras Blancas, and Point Buchon. Only data from 2008 and 2009 were included in comparisons of all locations because the Piedras Blancas location was not sampled in 2007. Analyses were essentially the same as the analysis of the old Point Lobos MPA; however, the scale of the measurements differed. In the Point Lobos analysis, fish were pooled within individual grid cells to serve as the sample units. In contrast, a population total for each metric was calculated for each of the new MPAs and reference areas by pooling the stomach contents of fish from multiple grid cells at each area, and these population totals served as the sample units.

Population total values were used because means based on averages of individual variation could
Table 2. Number of gopher rockfish stomachs analyzed by location, area, and year. MPA: marine protected area; REF: reference area

\begin{tabular}{|lcccc|}
\hline Location and area & 2007 & 2008 & 2009 & Total \\
\hline Año Nuevo MPA & 19 & 46 & 56 & 121 \\
Año Nuevo REF & 23 & 39 & 49 & 111 \\
Point Lobos Old MPA & 23 & 38 & 45 & 106 \\
Point Lobos New MPA & 20 & 15 & 41 & 76 \\
Point Lobos REF & 30 & 36 & 56 & 122 \\
Piedras Blancas MPA & 0 & 23 & 16 & 39 \\
Piedras Blancas REF & 0 & 14 & 30 & 44 \\
Point Buchon MPA & 11 & 18 & 22 & 51 \\
Point Buchon REF & 6 & 14 & 17 & 37 \\
Total & 132 & 243 & 332 & 707 \\
\hline
\end{tabular}

obscure differences at the population level. These population totals were calculated for each dietary measure (i.e. richness, evenness, composition) after summing stomach contents for 31 fish randomly drawn from each MPA and reference area. This number represents the smallest number of fish collected at a given area from 2008 to 2009 (Point Buchon reference area, Table 2) and was chosen to equalize sample sizes among areas.

Richness, evenness, and prey composition were compared inside and outside of MPAs using a randomized block design. The independent variable in all analyses was whether an area was designated as an MPA or as a reference area. In prey composition analysis, the number of prey categories was large relative to the number of samples and could introduce type I error; therefore, a PCA (Quinn \& Keough 2002) was performed on total prey weights prior to analysis to reduce prey composition into 2 factors, which served as the dependent variables. A reference area was paired geographically with each of the 4 MPAs, allowing geographic location to be used as a blocking factor in an RCB MANOVA (Quinn \& Keough 2002).

\section{Determining effects of other factors on diet}

The remainder of the study explored factors other than fishing exclusion that could affect gopher rockfish diet. Therefore, the following analyses were conducted without taking the effects of MPAs and reference areas into account, and examined overall fish density in an area regardless of its protected status as well as environmental variables.

Relationship between diet and fish density. Linear regressions were used to investigate the relationship between gopher rockfish density and dietary vari- 
ables. Mean prey taxon richness and evenness, trophic level, and IS were calculated for each sampling area as described above. Linear regressions were then used to test for relationships between these variables and the average gopher rockfish density in each area, expressed as catch per unit effort, which was calculated as the number of fish caught per angler hour spent fishing with standardized hook-and-line gear (Starr et al. 2010).

Relationship between diet and environmental variables. To investigate the potential influence of environmental variables on diet that could contribute to differences among geographic locations, a canonical correlation analysis (CCA, Quinn \& Keough 2002) was conducted using environmental and dietary variables calculated for each sampling grid cell. Environmental variables included depth, temperature at depth, area of hard substrate, and latitude. Depth of collection for each fish was measured using the boat's depth finder and was averaged for all fish collected within a grid cell. Temperature at depth was collected throughout the study in each grid cell using a continuously recording sensor lowered to $3 \mathrm{~m}$ above the seafloor, and measurements were averaged for each grid cell. The proportion of hard substrate within each grid cell was calculated in the software program ArcGIS 9.2 using habitat layers from the Seafloor Mapping Lab at California State University Monterey Bay. The habitat layers classified substrate as rock or sediment based on rugosity. Latitude data were taken from the coordinates of each sampling grid cell center point. Diet variables were calculated as standardized prey weights averaged for all fish caught in a given grid cell. CCA was performed using the software package PASW Statistics 18.0.

Relationship between diet and depth. A linear regression was used to further examine the relationship between diet and depth. PCA Factor 1 from the PCA analysis described above was used to summarize dietary variation. A linear regression was used to test for a relationship between the mean PCA Factor 1 score and the mean depth of fish collection at each sampling area.

\section{RESULTS}

In total, 1018 gopher rockfish were collected across 4 locations and $3 \mathrm{yr}$, of which 311 had empty stomachs $(30.6 \%)$. Diet composition was analyzed for the remaining 707 fish (Table 2). Fish total lengths ranged from 16.7 to $32.9 \mathrm{~cm}$, with a mean of $26.4 \mathrm{~cm}$. An RCB
ANOVA showed that length did not significantly differ inside and outside of MPAs $\left(F_{1,243}=1.944, \mathrm{p}=\right.$ $0.164)$; however, the block factor of geographic location was significant $\left(F_{3,243}=21.045, \mathrm{p}<0.001\right)$.

\section{Overall diet description and trophic level}

Gopher rockfish prey items represented 7 phyla and at least 60 distinct species (Table S1 in the Supplement at www.int-res.com/articles/suppl/m536 p229_supp.pdf). Overall, decapod crustaceans dominated the diet (70.04\% PSIRI) and consisted primarily of 20 different crab species (45.9\% PSIRI), shrimps $(14.5 \%$ PSIRI), and mysids (7.2\% PSIRI). Echinoderms, predominantly brittle stars, were also important to the diet (18.26\% PSIRI). The taxonomic group cephalopods consisted almost entirely of benthic Octopus sp. While most fishes had to be classified as unidentified due to their state of digestion, the majority of identified groups were benthic species (e.g. Cottidae, Gobiidae, Pleuronectiformes), although a few pelagic groups (e.g. Clupeidae, juvenile Sebastes) were also encountered. No significant relationship was observed between trophic level and total fish length $\left(p=0.23, R^{2}=0.003\right)$.

\section{Determining long-term effects of fishing exclusion at Point Lobos}

Richness and evenness. The number of stomachs used for dietary analyses at these sites was deemed sufficient. All cumulative prey curves reached an inflection point between 20 and 40 stomachs, and all curves reached an asymptote $(b<0.05)$, indicating sufficient sample size for prey taxon analysis.

There was no detectable difference in prey richness or evenness of gopher rockfish diet items between the old MPA and the pooled reference areas. The MANOVA revealed that diets from the old Point Lobos MPA and pooled reference areas did not differ significantly in mean prey taxon richness $\left(F_{1,210}=\right.$ $1.84, \mathrm{p}=0.18)$ or evenness $\left(F_{1,210}=1.04, \mathrm{p}=0.31\right)$. Overall prey diversity (the multivariate effect of richness and evenness) also did not differ between areas $\left(F_{2,209}=1.02, \mathrm{p}=0.36\right)$.

Prey composition. There were no detectable differences in prey taxon composition (as measured by Principal Components 1 and 2) between the old MPA and the reference areas.

Trophic level. More than $30 \mathrm{yr}$ of fishing exclusion did not appear to alter the TL of the gopher rockfish 
calculated from stomach contents. TL in the old Point Lobos MPA ranged from 3.16 to 4.24 , with a mean of 3.59 , as opposed to the pooled reference areas, which ranged from 3.10 to 4.24 with a mean of 3.56. The 2-tailed $t$-test showed that these differences were not significant $\left(t_{210}\right)=0.775, \mathrm{p}=$ 0.439).

Individual specialization. The extent of IS differed significantly between the old MPA and pooled reference areas. Mean IS, the overlap between individuals and their population, was 0.23 for the combined north and south reference areas, as opposed to a mean of 0.28 for the old MPA. The 2-tailed $t$-test showed that these differences were significant $\left(t_{201}\right)=$ 2.57, $\mathrm{p}=0.01$ ). Thus, in comparison to the old MPA, individuals in the reference area were on average $5 \%$ more specialized in relation to their population as a whole.

\section{Determining short-term effects of fishing exclusion in newly established MPAs}

Richness and evenness. The number of stomachs used for dietary analyses at these sites was deemed sufficient. All cumulative prey curves reached an inflection point between 20 and 40 stomachs. While some of the curve slopes for prey taxon analysis deviated from an asymptote, these deviations were likely caused by uncommon prey items and were thus not considered severe. Therefore, analyses were still performed using these prey taxonomic groups, while recognizing the potential underestimate of richness at these areas.

There were no detectable differences in prey taxon richness or evenness of gopher rockfish diet items between fish from new MPAs and fish from reference areas. The RCB MANOVA performed on population totals indicated that diets inside and outside of the new MPAs did not differ significantly in terms of taxon richness $\left(F_{1,3}=0.60, \mathrm{p}=0.50\right)$ or evenness $\left(F_{1,3}=4.16, \mathrm{p}=0.13\right)$. Overall diversity (multivariate effect of richness and evenness) also did not differ significantly inside and outside of MPAs $\left(F_{2,2}=7.14, \mathrm{p}=0.12\right)$. The block factor of geographic location was significant for taxon evenness $\left(F_{3,3}=47.49, \mathrm{p}=0.01\right)$ but not significant for total taxon richness $\left(F_{3,3}=1.00, \mathrm{p}=0.50\right)$ or diversity $\left(F_{6,6}=1.22, \mathrm{p}=0.41\right)$

Prey composition. Prey taxon composition did not differ significantly inside and outside of MPAs; however, significant differences were observed among geographic locations in terms of Factor 1 (Fig. 4). The first 2 principal components explained 33.9 and $22.1 \%$ of the variation, respectively.

Trophic level. Mean TLs were highly similar for all areas, ranging from 3.50 in the Point Buchon MPA to 3.61 in the Año Nuevo MPA. No significant differences in mean TL were observed inside versus outside new MPAs (ANOVA, $F_{1,3}=0.99, \mathrm{p}=0.39$ ). The block factor of geographic location was also not significant $\left(F_{3,3}=0.08, \mathrm{p}=0.97\right)$.

Individual specialization. No significant differences in mean IS were observed inside versus outside new MPAs (ANOVA, $F_{1,3}=0.66, \mathrm{p}=0.48$ ). The block factor of geographic location was also not significant $\left(F_{3,3}=0.91, \mathrm{p}=0.53\right)$. However, IS values were higher inside all MPAs except for the Año Nuevo MPA, suggesting a possible interaction between geographic location and MPA effect (Fig. 5).

\section{Determining effects of other factors on diet}

Relationship between diet and fish density. Gopher rockfish density was not related to most dietary metrics (Table 3). Linear regression analyses did not find significant relationships $(p>0.05)$ be-

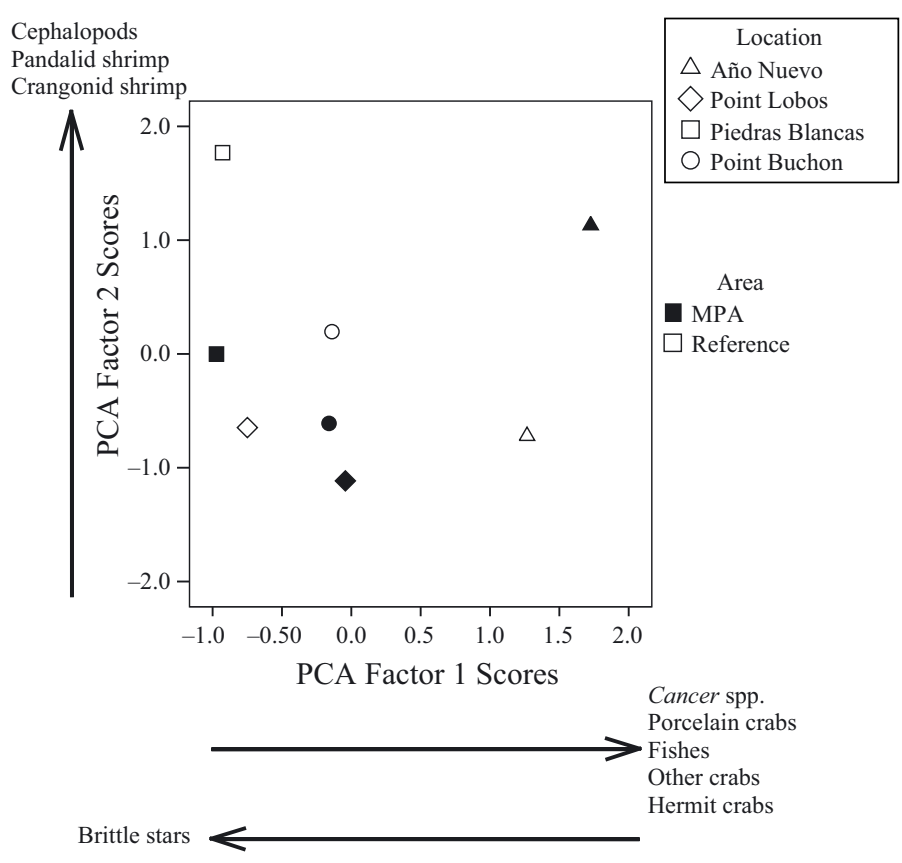

Fig. 4. Plot of principal components analysis (PCA) of prey taxa showing separation of Año Nuevo from other geographic areas along Factor 1. Black symbols indicate diet composition of specimens from marine protected areas (MPAs); white symbols represent reference areas. Arrows represent loadings greater than 0.70 


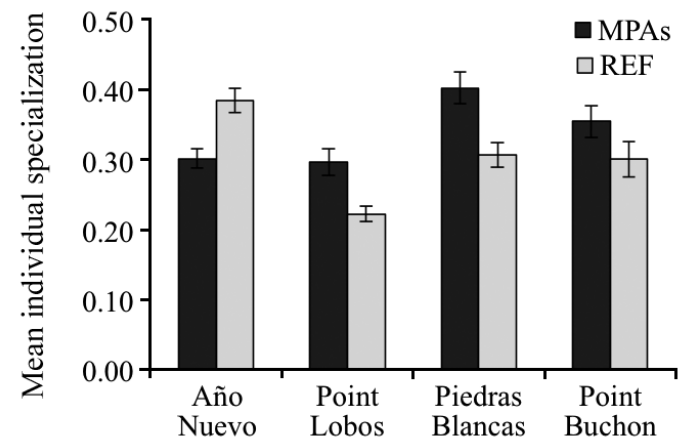

Fig. 5. Mean individual specialization (diet overlap between individuals and population) at new marine protected areas (MPAs) and reference (REF) areas showing no consistent difference among areas. Vertical bars represent standard error

Table 3. Relationship between diet metrics and gopher rockfish density

\begin{tabular}{|lccc|}
\hline Metric & $\mathrm{p}$ & $\mathrm{R}^{2}$ & Direction \\
\hline Taxon richness & 0.38 & 0.13 & None \\
Taxon evenness & 0.04 & 0.55 & Negative \\
Trophic level & 0.31 & 0.17 & None \\
Individual specialization & 0.99 & 0.17 & None \\
\hline
\end{tabular}

tween gopher rockfish density and prey taxon richness, trophic level, or IS. However, there was a significant and moderately strong negative relationship $\left(\mathrm{p}=0.04, \mathrm{R}^{2}=0.55\right)$ between prey taxon evenness and gopher rockfish density.

Relationship between diet and environmental variables. CCA showed a strong relationship between environmental variables and prey taxonomic groups (Table 4). The first canonical root $(r=0.80)$ was significantly different from zero $(p=0.01)$, and the environmental variables explained $5.1 \%$ of the overall variance of the dietary variables. Deeper depths and lower latitudes were associated with more brittle stars and fewer porcelain and Cancer spp.

Relationship between diet and depth. Plotting the PCA Factor 1 scores of prey taxon composition against average depth of fish collection revealed a significant, moderately strong relationship between diet and depth (Fig. 6, $\mathrm{p}=0.02, \mathrm{R}^{2}=0.61$ ). However, depth was confounded with geographic location. The average depth of fish collection ranged from $16.1 \mathrm{~m}$ at the Año Nuevo MPA to $28.8 \mathrm{~m}$ at the Point Buchon MPA.
Table 4. Summary of canonical correlation analysis performed on prey taxa. Canonical loadings are for the one significant root (CV1)

\begin{tabular}{|c|c|c|}
\hline Canonical variate/root & Canonical correlation & $\mathrm{p}$-value \\
\hline CV1 & 0.80 & 0.01 \\
\hline CV2 & 0.75 & 0.37 \\
\hline CV3 & 0.39 & 0.99 \\
\hline CV4 & 0.31 & 0.99 \\
\hline \multicolumn{3}{|l|}{ CV1 canonical loading } \\
\hline \multirow[t]{4}{*}{ Environmental variable } & Depth & -0.86 \\
\hline & Latitude & 0.78 \\
\hline & Proportion of rocky substrate & 0.42 \\
\hline & Temperature at depth & 0.05 \\
\hline \multirow{18}{*}{ Dietary variable } & Amphipod & -0.22 \\
\hline & Brittle star & -0.53 \\
\hline & Cancer spp. & 0.69 \\
\hline & Cephalopod & 0.12 \\
\hline & Crangonid shrimp & -0.01 \\
\hline & Fish & -0.07 \\
\hline & Hermit crab & -0.03 \\
\hline & Hippolytid shrimp & 0.44 \\
\hline & Isopod & -0.05 \\
\hline & Kelp crab & -0.12 \\
\hline & Mollusc & -0.02 \\
\hline & Mysids & 0.06 \\
\hline & Other crab & 0.16 \\
\hline & Pandalid shrimp & -0.02 \\
\hline & Pistol shrimp & 0.00 \\
\hline & Polychaete & -0.24 \\
\hline & Porcelain crab & 0.58 \\
\hline & Spider crab & 0.04 \\
\hline
\end{tabular}

\section{DISCUSSION}

The case study of the Point Lobos State Marine Reserve provides evidence that midlevel trophic changes in MPAs are not guaranteed. Despite greater fish density inside the MPA, gopher rockfish diets were not markedly different from nearby unprotected areas after $35 \mathrm{yr}$ of fishing exclusion. The finding of greater IS outside the MPA is the opposite of what competition theory would predict, although a statistically significant difference in specialization of $5 \%$ may not be ecologically significant. While changes in fish abundance and biomass can occur rapidly once protected areas are established (Halpern \& Warner 2002), associated changes in species composition and trophic structure may occur gradually and over timeframes of 10 to $15 \mathrm{yr}$ (Micheli et al. 2004, Babcock et al. 2010). Thus, increased fish densities may not produce changes to trophic structure or prey species composition in the central California MPAs, or such changes may take even longer to occur.

Without a historical baseline at Point Lobos, it is not possible to say that gopher 


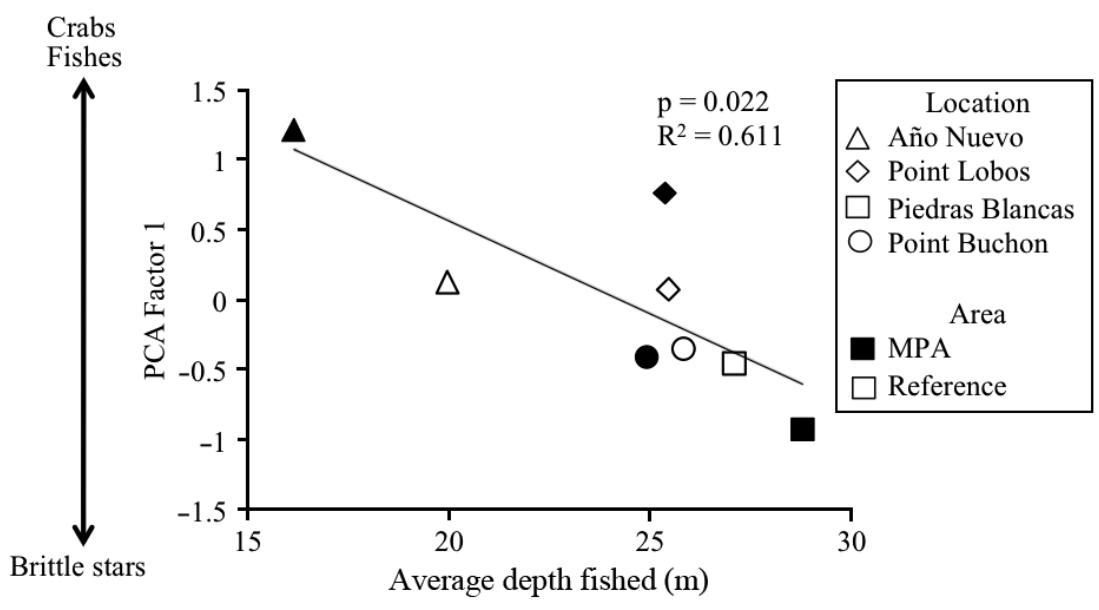

Fig. 6. Relationship between diet and depth showing that depth is confounded with geographic location. The $y$-axis represents the principal components analysis (PCA) Factor 1 scores for prey composition depicted in Fig. 4

MPAs included in this study were observed to be 1.4 to 2.0 times greater than those of the corresponding reference areas (Fig. 3, Starr et al. 2010). In contrast, Svanbäck \& Bolnick (2007) documented increased specialization in stickleback diets at a high-density treatment with 3 times the number of fish as low-density treatments. MPAs do show potential for increasing fish densities to substantially greater numbers than fished areas: fish densities in protected areas have been documented to be 8 (Babcock et al. 1999), 10 (Fanelli et al. 2010), and even 14 times greater than in fished areas (Willis et al. 2003). Diet evenness, another measure of specialization, did

rockfish feeding habits have not changed in $35 \mathrm{yr}$ but only that diets did not differ compared to the fished reference areas. While recreational and commercial fishing with hook and line and traps do occur in the reference areas, this fishing pressure may not be extensive enough to produce drastic differences in feeding dynamics compared to the protected area. The old Point Lobos MPA is also a small reserve, and different trends may occur in larger protected areas. This underscores the importance of collecting sitespecific baseline information and monitoring the performance of reserves individually as well as collectively.

Although controlled experimental work with sticklebacks suggests that IS and among-individual diet variability should increase with conspecific density (Svanbäck \& Bolnick 2007), there was no consistent effect associated with increased gopher rockfish densities in the MPAs surveyed. Significantly greater IS compared to the reference area was measured in the Año Nuevo MPA, and while this result is consistent with competition theory, all other MPAs exhibited lower IS than their reference areas (or higher overlap between individuals and the overall population), which is the opposite of what competition theory predicts. The differing effect of the MPA at Año Nuevo suggests that there may be some interaction with geography that could affect MPA performance.

The lack of differences in diet inside and outside of all MPAs surveyed suggests that although the densities of gopher rockfish inside MPAs are statistically greater than in the reference areas, the magnitude of these differences may not be substantial enough to produce density-dependent changes in fish diets. Gopher rockfish densities in the central California decrease with increasing gopher rockfish density across areas in the present study, which exhibited a 3-fold difference in density. Thus, density-driven feeding changes may yet be observed if fish densities in the central California MPAs increase over time. The relationship between fish density and individual diets may also not be a linear function, and fish densities may need to cross a threshold before trophic changes occur.

While this study primarily focused on the effects of intraspecific density on diet, interspecific interactions may also influence gopher rockfish feeding habits. Co-occurring species that exploit similar prey resources include the black-and-yellow rockfish Sebastes chrysomelas, brown rockfish $S$. auriculatus, China rockfish $S$. nebulosus, copper rockfish $S$. caurinus, kelp rockfish $S$. atrovirens, grass rockfish $S$. rastrelliger, treefish S. serriceps, and cabezon Scorpaenichthys marmoratus (Hallacher \& Roberts 1985, Lea et al. 1999, Love et al. 2002). Monitoring of the central coast MPAs revealed that densities of these species tended to be higher inside the MPAs than outside, although these differences were not significant (Starr et al. 2010). Greater densities of interspecific as well as intraspecific competitors would presumably amplify the effects of competition inside the MPAs. However, no evidence of competitive effects, such as decreased richness or increased specialization, was observed in MPAs, suggesting that any differences in the density of other fish competitors are not substantial enough to impact gopher rockfish feeding interactions.

Competition theory lays the groundwork for increased specialization and resource use diversification by positing that individuals switch or restrict 
their resource use as resources become scarce (Svanbäck \& Bolnick 2007). However, prey resources may not be limiting at the areas sampled in this study. The central California coast is a highly productive system that may be able to support rockfish populations at densities greater than those observed. The finding of no significant difference in prey richness inside and outside of the MPAs suggests that a similar suite of prey types is available to gopher rockfish at nearby locations irrespective of protected status, and indicates that the greater numbers of fish inside the MPAs have not depleted any major prey groups. Moreover, increased fish densities also do not necessarily guarantee changes in their feeding ecology (Badalamenti et al. 2008). Previous findings of significant diet differences inside and outside of protected areas are likely due to habitat modification and changes in prey availability caused by trawling (Fanelli et al. 2009, 2010). However, because small invertebrate species were found to be the primary prey, the fishing practices of hook-and-line and trapping gear used in this study location were unlikely to directly affect the availability of gopher rockfish prey.

Differences in depth among the geographic locations appear to account for some of the differences in prey composition observed at the new MPAs. Fish from Año Nuevo, which were collected at shallower depths than other locations, ate more Cancer and porcelain crabs, which may be due to the low intertidal and shallow subtidal distribution of these species (Morris et al. 1980). Brittle stars, such as Ophiothrix spiculata, were important prey in fish collected at deeper depths in Point Lobos and Piedras Blancas, and indeed this species has a depth distribution that extends to over $2000 \mathrm{~m}$ (Morris et al. 1980). However, Cancer and porcelain crabs do also occur at deeper depths (90 to $100 \mathrm{~m}$ ), and brittle stars can likewise inhabit the shallow regions of the low intertidal (Morris et al. 1980, Carroll \& Winn 1989). Thus, depth alone probably does not explain the differences in prey composition among geographic locations, and other habitat features are likely important. The patterns in prey composition observed mirror those of groundfish species composition at these MPAs, where the greatest differences in species composition occurred among locations rather than inside and outside of MPAs (Starr et al. 2010). These results suggest that nearshore kelp forest and rocky reef communities are not uniform along the central California coast.

An investigation into the abundance and distribution of various prey species at each area was beyond the scope of this study, as many of the species eaten by the gopher rockfish are small and cryptic and are not included in subtidal invertebrate surveys. Subtidal surveys conducted by the Partnership for Interdisciplinary Studies of Coastal Oceans in the general geographic regions included in this study documented larger organisms like bat stars and anemones but not most species consumed by the gopher rockfish. Based on the assumption that a generalist predator will show little selectivity in feeding, the stomach contents of generalist feeders can be used as a means to sample the marine environment (Frid \& Hall 1999, Link 2004). The large number of prey types encountered in this study supports the assumption that gopher rockfish are not highly discriminate feeders. Thus, these results provide a partial characterization of the cryptic invertebrate communities of these MPAs and reference areas, as sampled by the gopher rockfish.

The present study provides several contributions to the management of marine resources and the understanding of MPAs. This study did not document trophic changes after $35 \mathrm{yr}$ of protection in the Point Lobos MPA, which suggests that trophic changes should not necessarily be expected to occur once MPAs are implemented. Furthermore, no consistent differences in feeding ecology were observed in new MPAs, despite greater densities of gopher rockfish inside 3 of the 4 MPAs surveyed. This may indicate that the food web is relatively stable at these locations, and increased densities may not necessarily be detrimental to gopher rockfish inside MPAs.

The differences in diet among geographic locations revealed in this study suggest that food web changes associated with MPAs may be location specific. This underscores the importance of considering sitespecific differences when assessing the collective performance of many MPAs. California's network of MPAs, spanning the entire coastline, is now being monitored in regions; however, the differences observed among MPAs in the central California region in this study suggest it may be necessary to group MPAs at a finer geographic scale to assess their overall effects. MPAs are intended to protect the entire ecosystem within their borders, often with the added hope of increasing fish abundances. To understand the full ecological implications of establishing MPAs, it is important to know how the effects of fish abundance could influence the food web. The central California MPAs show the potential to increase the size and density of some fish species within their borders, which may eventually lead to shifts in fish feeding ecology. Accounting for location-specific differences 
like those observed in this study is important to understand how each MPA performs over time and should be considered when investigating general MPA effectiveness.

Acknowledgements. The authors thank all of the California Collaborative Fisheries Research Program staff, boat captains, and volunteer anglers who helped collect fish and other data for this project. In particular, we thank Noëlle Yochum, Cassandra Brooks, Katie Schmidt, Jahnava Duryea, Selena McMillan, and Leslie Longabach. We also thank all of the people who helped record data during fish dissections, especially Kara Ritchie. Cristie Boone, Scott Hamilton and Jim Watanabe contributed expert advice. Kristin Hunter-Thomson, Elsie Tanadjaja, and Corina Marks assisted with programming, figure editing, and map making. This project was funded in part by the California Sea Grant College Program through project R/ENV-213EPD and was conducted under Institutional Animal Care and Use Committee Protocol \#824.

\section{LITERATURE CITED}

Allison GW, Lubchenco J, Carr MH (1998) Marine reserves are necessary but not sufficient for marine conservation. Ecol Appl 8:S79-S92

Amundsen PA, Gabler HM, Staldvik FJ (1996) A new approach to graphical analysis of feeding strategy from stomach contents data-modification of the Costello (1990) method. J Fish Biol 48:607-614

Babcock RC, Kelly S, Shears NT, Walker JW, Willis TJ (1999) Changes in community structure in temperate marine reserves. Mar Ecol Prog Ser 189:125-134

Babcock RC, Shears NT, Alcala AC, Barrett NS and others (2010) Decadal trends in marine reserves reveal differential rates of change in direct and indirect effects. Proc Natl Acad Sci USA 107:18256-18261

Badalamenti F, Sweeting C, Polunin N, Pinnegar J and others (2008) Limited trophodynamics effects of trawling on three Mediterranean fishes. Mar Biol 154:765-773

Bizzarro J, Robinson H, Rinewalt C, Ebert D (2007) Comparative feeding ecology of four sympatric skate species off central California, USA. Environ Biol Fishes 80:197-220

Bolnick DI, Yang LH, Fordyce JA, Davis JM, Svanback R (2002) Measuring individual-level resource specialization. Ecology 83:2936-2941

Botsford LW, Castilla JC, Peterson CH (1997) The management of fisheries and marine ecosystems. Science 277 : 509-515

Brown WL Jr, Wilson EO (1956) Character displacement. Syst Zool 5:49-64

Brown SC, Bizzarro JJ, Cailliet GM, Ebert DA (2012) Breaking with tradition: redefining measures for diet description with a case study of the Aleutian skate Bathyraja aleutica (Gilbert 1896). Environ Biol Fishes 95:3-20

Carlton JT (ed) (2007) The Light and Smith manual: intertidal invertebrates from central California to Oregon, 4th edn. University of California Press, Berkeley, CA

Carroll JC, Winn RN (1989) Species profiles: life histories and environmental requirements of coastal fishes and invertebrates (Pacific Southwest) - brown rock crab, red rock crab, and yellow crab. US Fish Wildl Serv Biol Rep
82(11.117), US Army Corps of Engineers, TR EL-82-4, Vicksburg, MS

Clemente S, Hernández JC, Brito A (2009) Evidence of the top-down role of predators in structuring sublittoral rocky-reef communities in a marine protected area and nearby areas of the Canary Islands. ICES J Mar Sci 66: 64-71

Cortés E (1997) A critical review of methods of studying fish feeding based on analysis of stomach contents: application to elasmobranch fishes. Can J Fish Aquat Sci 54: 726-738

> Cortés E (1999) Standardized diet compositions and trophic levels of sharks. ICES J Mar Sci 56:707-717

> Crowder LB, Hazen EL, Avissar N, Bjorkland R and others (2008) The impacts of fisheries on marine ecosystems and the transition to ecosystem-based management. Annu Rev Ecol Evol Syst 39:259-278

- Ebert DA, Bizzarro JJ (2007) Standardized diet compositions and trophic levels of skates (Chondrichthyes: Rajiformes: Rajoidei). Environ Biol Fishes 80:221-237

Fanelli E, Badalamenti F, D'Anna G, Pipitone C (2009) Diet and trophic level of scaldfish Arnoglossus laterna in the southern Tyrrhenian Sea (western Mediterranean): contrasting trawled versus untrawled areas. J Mar Biol Assoc UK 89:817-828

Fanelli E, Badalamenti F, D'Anna G, Pipitone C, Romano C (2010) Trophodynamic effects of trawling on the feeding ecology of pandora, Pagellus erythrinus, off the northern Sicily coast (Mediterranean Sea). Mar Freshw Res 61: 408-417

Fanshawe S, Vanblaricom GR, Shelly AA (2003) Restored top carnivores as detriments to the performance of marine protected areas intended for fishery sustainability: a case study with red abalones and sea otters. Conserv Biol $17: 273-283$

Ferry LA, Cailliet GM (1996) Sample size and data analysis: Are we characterizing and comparing diet properly? In: MacKinlay D, Shearer K (eds) Feeding ecology and nutrition in fish: Proceedings of the symposium on the feeding ecology and nutrition in fish. International Congress on the Biology of Fishes, July 14-18, 1996, San Francisco, CA, p 1-80

> Frid CLJ, Hall SJ (1999) Inferring changes in North Sea benthos from fish stomach analysis. Mar Ecol Prog Ser 184: 183-188

Guidetti P (2006) Marine reserves reestablish lost predatory interactions and cause community changes in rocky reefs. Ecol Appl 16:963-976

Guidetti P, Sala E (2007) Community-wide effects of marine reserves in the Mediterranean Sea. Mar Ecol Prog Ser 335:43-56

Hallacher L, Roberts D (1985) Differential utilization of space and food by the inshore rockfishes (Scorpaenidae: Sebastes) of Carmel Bay, California. Environ Biol Fishes 12:91-110

> Halpern BS, Warner RR (2002) Marine reserves have rapid and lasting effects. Ecol Lett 5:361-366

> Hyslop EJ (1980) Stomach contents analysis - a review of methods and their application. J Fish Biol 17:411-429

Key M, MacCall AD, Bishop T, Leos B (2005) Stock assessment of the gopher rockfish (Sebastes carnatus). In: Status of the Pacific coast groundfish fishery through 2005, stock assessment and fishery evaluation, Vol 5: stock assessments and rebuilding analyses. Pacific Fishery Management Council, Portland, OR 
Krebs CJ (1999) Ecological methodology, 2nd edn. AddisonWesley Educational Publishers, Menlo Park, CA

Lance MM, Orr AJ, Riemer SD, Weise MJ, Laake JL (2001) Pinniped food habits and prey identification techniques protocol. AFSC Processed Report 2001-04. Alaska Fish Sci Cent, NMFS, NOAA, Seattle, WA

Larson RJ (1980) Territorial behavior of the black and yellow rockfish and gopher rockfish (Scorpaenidae, Sebastes). Mar Biol 58:111-122

Lea RN, McAllister RD, VenTresca DA (1999) Biological aspects of nearshore rockfishes of the genus Sebastes from central California with notes on ecologically related sport fishes. Fish Bull 177, Calif Dep Fish Game, Sacramento, CA

Lester SE, Halpern BS, Grorud-Colvert K, Lubchenco J and others (2009) Biological effects within no-take marine reserves: a global synthesis. Mar Ecol Prog Ser 384: $33-46$

Link JS (2004) Using fish stomachs as samplers of the benthos: integrating long-term and broad scales. Mar Ecol Prog Ser 269:265-275

Love MS, Yoklavich M, Thorsteinson L (2002) The rockfishes of the northeast Pacific. University of California Press, Berkeley, CA

> McClanahan TR (2000) Recovery of a coral reef keystone predator, Balistapus undulatus, in East African marine parks. Biol Conserv 94:191-198

McClanahan TR, Arthur R (2001) The effect of marine reserves and habitat on populations of East African coral reef fishes. Ecol Appl 11:559-569

Micheli F, Halpern BS, Botsford LW, Warner RR (2004) Trajectories and correlates of community change in no-take marine reserves. Ecol Appl 14:1709-1723

Morris RH, Abbott DP, Haderlie EC (1980) Intertidal invertebrates of California. Stanford University Press, Stanford, CA

Mumby PJ, Harborne AR, Williams J, Kappel CV and others (2007) Trophic cascade facilitates coral recruitment in a marine reserve. Proc Natl Acad Sci USA 104:8362-8367

Oksanen J, Blanchet F, Kindt R, Legendre P and others (2010) Vegan: community ecology package. R package

Editorial responsibility: Janet Ley, St. Petersburg, Florida, USA version 1.17-2. http://cran.r-project.org/package=vegan Pinkas L, Oliphant MS, Iverson ILK (1971) Food habits of albacore, bluefin tuna, and bonito in California waters. Fish Bull 152, Calif Dep Fish Game, Sacramento, CA

> Pinnegar JK, Polunin NVC, Francour P, Badalamenti F and others (2000) Trophic cascades in benthic marine ecosystems: lessons for fisheries and protected-area management. Environ Conserv 27:179-200

Quinn GP, Keough MJ (2002) Experimental design and data analysis for biologists. Cambridge University Press, Cambridge

Sinopoli M, Fanelli E, D'Anna G, Badalamenti F, Pipitone C (2012) Assessing the effects of a trawling ban on diet and trophic level of hake, Merluccius merluccius, in the southern Tyrrhenian Sea. Sci Mar 76:677-690

Starr RM, Wendt D, Schmidt KT, Romero R and others (2010). Baseline surveys of nearshore fishes in and near central California marine protected areas 2007-2009. Ocean Protection Council, California Sea Grant College Program, San Diego, CA

Starr RM, Wendt DE, Barnes CL, Marks CI and others (2015) Variation in responses of fishes across multiple reserves within a network of marine protected areas in temperate waters. PLoS ONE 10:e0118502

Svanbäck R, Bolnick DI (2007) Intraspecific competition drives increased resource use diversity within a natural population. Proc R Soc B 274:839-844

Tetreault I, Ambrose RF (2007) Temperate marine reserves enhance targeted but not untargeted fishes in multiple no-take MPAs. Ecol Appl 17:2251-2267

Wendt DE, Starr RM (2009) Collaborative research: an effective way to collect data for stock assessments and evaluate marine protected areas in California. Mar Coast Fish $1: 315-324$

Willis TJ, Millar RB, Babcock RC (2003) Protection of exploited fish in temperate regions: high density and biomass of snapper Pagrus auratus (Sparidae) in northern New Zealand marine reserves. J Appl Ecol 40:214-227

Yochum N, Starr RM, Wendt DE (2011) Utilizing fishermen knowledge and expertise: keys to success for collaborative fisheries research. Fisheries 36:593-605

Submitted: January 2, 2015; Accepted: July 9, 2015

Proofs received from author(s): September 16, 2015 